\section{Leaf Area Distribution of Tomato Plants as Influenced by Polyethylene Mulch Surface Color}

\author{
Dennis R. Decoteau
}

AdDITIONAL INDEX wORDs. Lycopersicon esculentum, canopy, nodal partitioning

Summary. The influence of polyethylene (plastic) mulch surface color (white versus black) on leaf area distribution of tomato (Lycopersicon esculentum) was investigated in simulated planting beds at two sampling periods: an early sampling with relatively young plants that had been in the mulch treatment for 22 days and a late sampling with relatively mature plants that had been in the mulch treatments for $\mathbf{5 0}$ days. At the early sampling period, tomato plants grown with white mulch had more axillary leaves than plants in the black mulch, resulting in a greater axillary:main leaf area ratio for the plants with white mulch. Leaf area for total leaves (main + axillary) and plant biomass was unaffected by mulch surface color at the early sampling period. Tomato plants grown in black mulch at the early sampling period had significantly more area of main leaves partitioned to node 3 , whereas plants grown in white mulch had more area of main leaves in nodes 8 and 9. Plants grown in the white mulch treatment had significantly more axillary leaf area at nodes 1,2 , and 3 , whereas plants in black mulch had more axillary leaf area at node 6. At the later sampling period, most of the leaf area from both mulch treatments was recorded in the axillary leaves and there was no effect of mulch surface color on the amount of total leaf area partitioned to main, axillary, or total leaves; to the amount of biomass of the measured top growth; or to the nodal distribution of leaf area among main leaves or axillary leaves. Tomato plants in white mulch had significantly more fruit on plants at the later sampling period than plants in the black mulch. Mulch surface color also affected the plant light environment and soil temperatures. These results suggest that the polyethylene mulch surface color can induce changes in the plant microclimate and affect leaf area distribution of young tomato plants (as recorded at the early sampling) and fruiting of relatively more mature plants (as recorded at the later sampling).

$\mathrm{T}$ The foliage of mature tomato plants typically consists of leaves that are initiated from the apical meristem (referred to as main or "true" leaves) or from axillary meristems (referred to as axillary leaves or "suckers") (Decoteau, 1990). The initiation of main leaves in tomato is regulated by environmental factors such as temperature (Paul, 1984a, 1984b) and light (Hussey, 1963). Axillary leaf initiation and growth in tomato appears to be more precocious than for the main leaves (Decoteau, 1990; Tucker, 1977), and the factors involved in regulating axillary initiation and growth are not well understood.

Leaf area distribution in a tomato canopy is important for maximizing plant photosynthetic capacity (Wolk et al., 1983) and protecting developing fruit from excessive exposure to

Department of Horticulture, 103 Tyson Building, The Pennsylvania State University, University Park, PA 16802-4200

E-mail: drd10@psu.edu. solar radiation (Andegoroye and Jolliffe, 1983). Removal or loss of main leaves or decapitation (or removal of the apical bud) enhances the growth of axillary leaves (Decoteau, 1990), whereas the removal or loss of axillary leaves has a lesser effect on the growth of the main leaves (Aung and Kelly, 1966; Decoteau, 1990).

The relative amount of axillary leaves to main leaves appears to exert an influence on subsequent tomato fruit production. A large number of axillary leaves present on the plant during the vegetative growth phase often delays initiation of the reproductive phase. In addition, the resulting fruit are smaller than those produced from tomato plants that had many of their axillary leaves removed (Decoteau, 1990).

Various cultural practices and environmental factors have profound effects on crop development resulting in modified overall canopy structure and appearance. In commercial tomato production, polyethylene (plastic) mulches are often used to increase yields (Jones et al., 1977; Kasperbauer and Hunt, 1998; Orzolek et al., 2000; Wien and Minotti, 1987), enhance fruit quality (Wien and Minotti, 1987), and reduce weed pressure (Smith, 1968). The beneficial effects attributed to the use of plastic mulch appear directly related to changes in plant microclimate (Decoteau, 2005; Decoteau et al., 1986; Kasperbauer and Hunt, 1998). We have previously reported that mulch surface color can influence tomato plant growth (Decoteau et al., 1988; Fortnum et al., 2000) and fruit yield (Decoteau et al., 1989; Fortnum et al., 1997). For example, plants grown over white mulch were shorter and branched earlier than plants grown over black mulch and overall canopy structure appeared different (Decoteau et al., 1988).

Dry or fresh plant weight (biomass) and amount of foliage (leaf area) are commonly used measurements for documenting differences in plant development among experimental mulch color treatments (Decoteau et al., 1988; Fortnum et al., 2000). These growth measurements often do not account for biomass distribution differences that may be occurring among plant parts at individual nodes that contribute to overall shape and structure of the crop canopy. The objective of this study was to document the influence of polyethylene mulch surface color on leaf area distribution as measured at two sampling periods: an early

\begin{tabular}{llll}
\hline $\begin{array}{l}\text { Units } \\
\text { To convert U.S. to } \\
\text { SI, multiply by }\end{array}$ & U.S. unit & SI unit & $\begin{array}{l}\text { To convert SI to } \\
\text { U.S., multiply by }\end{array}$ \\
\hline 0.3048 & $\mathrm{ft}$ & $\mathrm{m}$ & 3.2808 \\
2.5400 & inch(es) & $\mathrm{cm}$ & 0.3937 \\
6.4516 & inch & $\mathrm{cm}^{2}$ & 0.1550 \\
1.1209 & $\mathrm{lb} / \mathrm{acre}$ & $\mathrm{kg} \cdot \mathrm{ha}^{-1}$ & 0.8922 \\
0.0254 & $\mathrm{mil}$ & $\mathrm{mm}$ & 39.3701 \\
28.3495 & $\mathrm{oz}$ & $\mathrm{g}$ & 0.0353 \\
$\left({ }^{\circ} \mathrm{F}-32\right) \div 1.8$ & ${ }^{\circ} \mathrm{F}$ & ${ }^{\circ} \mathrm{C}$ & $\left(1.8 \times{ }^{\circ} \mathrm{C}\right)+32$
\end{tabular}


sampling period with relatively young plants that had been in the mulch treatment for $22 \mathrm{~d}$ and a late sampling period with relatively mature plants that had been in the mulch treatments for $50 \mathrm{~d}$.

\section{Materials and methods}

Simulated planting beds previously described by Fortnum et al. (2000) and located in a glass greenhouse (maximum temperature $85^{\circ} \mathrm{F}$ and minimum temperature $65^{\circ} \mathrm{F}$ ) were used in the evaluation to ensure that no leaf area or plant biomass was destroyed or lost before harvest. The plant beds $(12 \mathrm{ft}$ long $\times 3 \mathrm{ft}$ wide $\times 1 \mathrm{ft}$ deep) containing sterilized Norfolk loamy sand soil were fertilized with nitrogen, phosphorus, and potassium rates of 100,140 , and $275 \mathrm{lb} /$ acre and incorporated into the top 6 inches of soil. Lime was applied according to soil test results. A single-drip tubing irrigation tape running the length of the bed was used to provide water as needed for optimum plant growth.

Black polyethylene (1 mil thick and $4 \mathrm{ft}$ wide) was placed over the soil and drip tape with the edges secured in between the inner side of the plant bed and the soil, thereby completely covering the soil surface. The white mulch treatment was obtained by painting white latex paint (Rustoleum Gloss White No. 7792; Rustolem Brands, Vernon Hills, IL) over the black polyethylene surface. Painting the black mulch with white paint enabled better experimental control of the surface reflection properties than if white plastic was used (because white plastics have different reflective properties depending on the manufacturer and formulation). The black mulch treatment was unpainted. The polyethylene mulch color plots were $6 \mathrm{ft}$ in length with two plots per bed with the mulch color treatments arranged in a split plot design with six replicates.

Five-week-old tomato 'Mountain Pride' tomato transplants were placed into the mulch treatments (four plants per plot) at in-row spacing (one row per bed) of 18 inches. Pesticides were not used because insects and diseases were not present during the evaluation. The two center plants from each plot were sacrificed for biomass and leaf area determination after $22 \mathrm{~d}$ (early sampling) in the mulch treatment and the remaining two plants were sacrificed for sampling after $50 \mathrm{~d}$ (late sampling) in the mulch treatment.

Leaf area, as measured with an area meter (model 3100; LI-COR Biosciences, Lincoln, NE), was recorded at each node for each sampled plant and separated according to main (true) leaves or axillary leaves (those arising from axillary buds). Leaf nodes were numbered from the cotyledon upward. These values were then plotted on a horizontal bar graph for visualization of canopy structure according to leaf area partitioning among nodes (Decoteau, 1990). The number and fresh weight of all fruit present on the plants was also recorded. Dry weight of leaves and stems was measured after complete drying at $106{ }^{\circ} \mathrm{C}$. Results were statistically tested by analysis of variance and least significant difference values were calculated for use in pairwise comparison of treatment means.

The amount of photosynthetically active radiation $(P A R$; incident quantum flux in the waveband 400 to $700 \mathrm{~nm}$ ) and the spectral distribution of surface-reflected light (quantum flux from 350 to $850 \mathrm{~nm}$ ) from the mulch treatments was measured 4 inches above the mulch surface on a cloudless day at solar noon at 5-nm intervals using a spectroradiometer (model 1800; LI-COR Biosciences) with a remote light collector on a $1.5-\mathrm{m}$ fiberoptic probe. The reflected light values are expressed as a percentage of direct sunlight at each measured wavelength (Decoteau et al., 1988). Irradiance levels of 650 and $735 \mathrm{~nm}$ were used to calculate the red [R $(600$ to $700 \mathrm{~nm})]$ to far-red [FR $(700$ to $770 \mathrm{~nm})]$ ratios because these represent phytochrome action peaks in green plants (Kasperbauer et al., 1964). The R:FR ratio of direct sunlight was assigned a value of 1.0. Soil temperatures at a l-inch depth were automatically measured in the center of each plot at 1-min intervals during the $50 \mathrm{~d}$ of the experiment with a data logger (model CR7; Campbell Scientific, Logan, UT) and copper constantan fixed thermocouples.

\section{Results and discussion}

At the early sampling period (22 d in mulch treatment), there was no significant polyethylene mulch surface color effect on the amount of biomass (leaf + stem) produced per plant (Table 1). Mulch surface color affected the amount of leaf area of the axillary leaves, but not the main leaves. The plants grown with white mulch had $\approx 3$ times more axillary leaves than plants in the black mulch and this contributed to the 3.6 times greater axillary:main leaf area ratio for the plants in the white mulch. The increase in lateral shoots in white mulch treatments had been previously observed (Fortnum et al., 2000 ) and was attributed to the lower ratio of $R$ to $F R$ light reflected into the plant canopy from the white mulch treatments as compared with the black treatments. Total leaf area (main + axillary) was unaffected by mulch surface color.

Leaf area distribution of main leaves in both color treatments at the early sampling period (Fig. 1A) and later sampling period (Fig. IC) was greater in the center nodes than the older, lower nodes or the younger, upper nodes. This is in agreement with previous observations of tomato leaf area distribution of relatively young tomato plants that had been decapitated, pruned, or not had any leaves or plant parts removed (Decoteau, 1990). This leaf partitioning pattern gives the tomato its characteristic bushy appearance.

Polyethylene mulch surface color did affect the nodal distribution of the leaf area in the plant canopy of relatively young plants at the early sampling period. Tomato plants grown with the black mulch had significantly more area of main leaves partitioned to node 3 than plants grown in the white treatment (Fig. 1A), whereas plants grown with white mulch had more area of main leaves partitioned to nodes 8 and 9 than plants grown in the black mulch treatment. There were significant increases in area of axillary leaves at nodes 1,2 , and 3 for plants in the white mulch treatment (Fig. 1B) than in the black mulch treatment. Black mulch treatment significantly increased the amount of axillary leaf area at node 6 .

At the later sampling period $(50 \mathrm{~d}$ in mulch treatment), most of the leaf area from both mulch color treatments was recorded in the axillary leaves (Table 1; Fig. 1D). There was no effect of polyethylene mulch surface color on the amount of total leaf area partitioned to main, axillary, or 
Table 1. Mulch surface color effects on leaf area partitioning and biomass (leaf + stem dry weight) of tomato at an early sampling period (after $22 \mathrm{~d}$ in mulch treatments) and late sampling period (after $50 \mathrm{~d}$ in mulch treatments).

\begin{tabular}{|c|c|c|c|c|c|c|}
\hline \multirow{2}{*}{$\begin{array}{l}\text { Sampling } \\
\text { period }\end{array}$} & \multirow{2}{*}{$\begin{array}{l}\text { Mulch } \\
\text { color }\end{array}$} & \multicolumn{4}{|c|}{ Leaf area $\left(\mathrm{cm}^{2}\right)^{\mathrm{z}}$} & \multirow{2}{*}{$\begin{array}{c}\text { Biomass } \\
(\text { leaf }+ \text { stem }) \\
(\text { g dry wt })^{\mathrm{z}}\end{array}$} \\
\hline & & Total & Main & Axillary & Axillary:main & \\
\hline Early & White & 881.5 & 748.9 & 132.7 & 0.1843 & 33.2 \\
\hline Black & 772.0 & 727.8 & 44.3 & 0.0514 & 34.0 & \\
\hline Significance & NS & NS & * & ** & NS & \\
\hline Late & White & 13,731 & 1,744 & 11,987 & 9.92 & 108.3 \\
\hline Black & 12,822 & 2007 & 10,815 & 5.56 & 105.9 & \\
\hline Significance & NS & NS & NS & NS & NS & \\
\hline
\end{tabular}

${ }^{2} 1 \mathrm{~cm}^{2}=0.1550$ inch $^{2} ; 1 \mathrm{~g}=0.0353 \mathrm{oz}$.

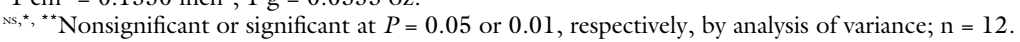

\section{Young Plants}
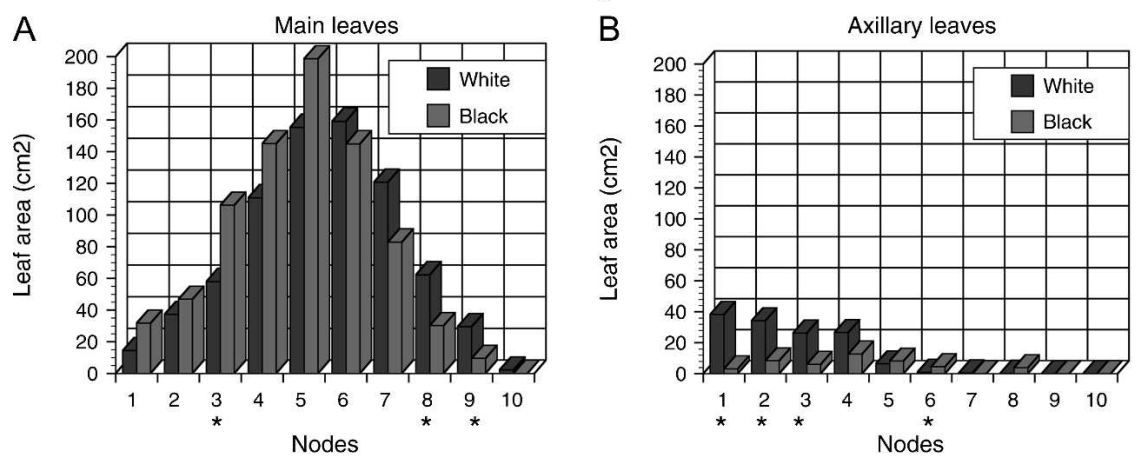

Mature Plants
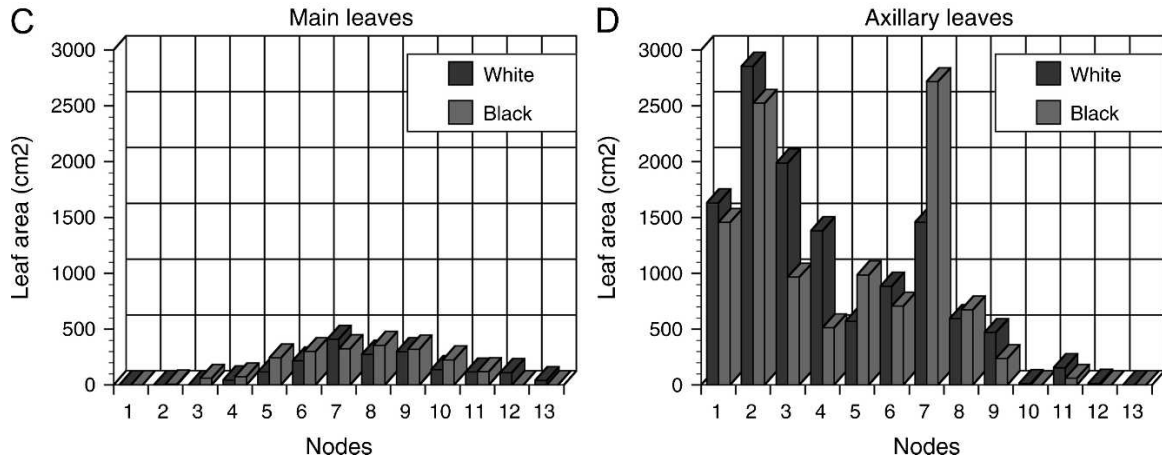

Fig. 1. Nodal leaf distribution of main leaves (A and C) and axillary leaves (B and D) of tomato from an early sampling period (after $22 \mathrm{~d}$ in mulch treatments) consisting of relatively young plants (A and $B$ ) and a late sampling period (after $50 \mathrm{~d}$ in mulch treatments) consisting of relatively mature plants ( $C$ and $D$ ) grown over white or black plastic mulch. Leaf nodes were numbered from the cotyledon upward. Statistical significance $(P=0.05)$ of a mulch surface color effect on leaf area at a node is indicated by an asterisk below the node number on the graph $\left(1 \mathrm{~cm}^{2}=0.1550\right.$ inch $\left.^{2}\right)$.

total leaves; to amount of biomass of the measured top growth (Table 1); or to the nodal distribution of leaf area of the main leaves (Fig. 1C) or axillary leaves (Fig. ID) at the later sampling period. This appears to conflict with our previous results of mulch color on season-long marketable fruit yield of field-grown tomatoes (Decoteau et al., 1989) that indicated that tomato plants grown
Table 2. Fruiting characteristics of tomato plants grown with white or black plastic mulch for $50 \mathrm{~d}$.

\begin{tabular}{|c|c|c|}
\hline Mulch color & $\begin{array}{c}\text { Fruit } \\
\text { (no./plant) }\end{array}$ & $\begin{array}{c}\begin{array}{c}\text { Fruit } \\
(\mathrm{g} / \text { plant })^{\mathrm{z}}\end{array} \\
\end{array}$ \\
\hline White & 24.7 & 1885 \\
\hline Black & 18.6 & 1525 \\
\hline Significance & * & NS \\
\hline
\end{tabular}

promote larger fruit) so as to determine mulch color effects on seasonlong marketable fruit yield, whereas the plants in the current study were grown in plant beds in a greenhouse for a maximum of $50 \mathrm{~d}$ (before bottom leaves began to senesce and abscise) and were not pruned so as to determine mulch color effects on leaf area development. The lack of observed growth effects resulting from mulch surface color at the later sampling period in the current study may also be a consequence of increased shading of the mulch by the plant canopies than at the earlier stage, thereby reducing the environmental modifications associated with the mulch treatments and the plants overcoming any growth-regulating effects observed as a result of the mulch color. Alternately, the more mature plants may not be as responsive to mulch surface color and became uniform in growth.

Tomato plants in white mulch had significantly more fruit per plant at the later sampling period than plants in the black mulch (Table 2). Most of the fruit on the plants at this sampling period had not reached the marketable stage, making comparisons to previous field yield results difficult. The plants in the white mulch may have set fruit earlier or had more fruit produced as a result of earlier lateral leaf formation. Mulches have been previously shown to influence flowering of tomato (Vanderberg and Tiessen, 1972) with mulch surface color affecting fruit yields (Decoteau et al., 1989). In addition, onset of flowering and early fruit set of tomato has been previously shown to exert subsequent effects on marketable fruit yield probably as a result of competition of photosynthate within the plant (Nesbitt and Tanksley, 2001). An increase in the total number of flowers could increase competition for photosynthates and 
Table 3. Mulch surface color effects on reflected light and on soil temperatures.

\begin{tabular}{|c|c|c|c|c|}
\hline \multirow{3}{*}{$\begin{array}{l}\text { Mulch } \\
\text { color }\end{array}$} & \multicolumn{3}{|c|}{ Reflected light } & \multirow{3}{*}{$\begin{array}{l}\text { Soil temp } \\
\quad\left({ }^{\circ} \mathbf{C}\right)^{\mathrm{y}}\end{array}$} \\
\hline & $\begin{array}{c}P A R^{\mathrm{x}} \\
(400-700 \mathrm{~nm}) \\
\end{array}$ & $\begin{array}{c}\text { Blue }^{w} \\
(400-500 \mathrm{~nm})\end{array}$ & $\begin{array}{l}\text { R:FR }{ }^{v} \text { relative to } \\
\text { direct sunlight }\end{array}$ & \\
\hline & \multicolumn{3}{|c|}{$\longrightarrow(\%$ of direct sunlight $)-$} & \\
\hline White & 47 & 46 & 1.00 & 22.9 \\
\hline Black & 6 & 6 & 0.94 & 23.7 \\
\hline
\end{tabular}

${ }^{\mathrm{z}}$ Light measurements were taken 4 inches $(10.2 \mathrm{~cm})$ above the plastic on a cloudless day at about solar noon, and soil temperatures are mean recorded values at a 1 -inch $(2.5-\mathrm{cm})$ depth averaged over $50 \mathrm{~d}$.

$\mathrm{y}\left(1.8 \times{ }^{\circ} \mathrm{C}\right)+32={ }^{\circ} \mathrm{F}$

'Photosynthetically active radiation measured as the incident quantum flux in the waveband $400-700 \mathrm{~nm}$.

"Blue light measured as the incident quantum flux in the waveband $400-500 \mathrm{~nm}$.

${ }^{v}$ Red $(600-700 \mathrm{~nm})$ to far-red $(700-770 \mathrm{~nm})$ ratio (R:FR) measured as incident quantum flux of $650 \mathrm{~nm}$ to incident quantum flux of $735 \mathrm{~nm}$. The R:FR ratio of direct sunlight was assigned a value of 1.0 .

decrease tomato fruit size. This size reduction effect can be the result of both competition between inflorescences (Fisher, 1977) or among fruit on a single inflorescence (Veliath and Ferguson, 1972).

Upwardly reflected light off the polyethylene mulch influenced the light environment in the seedling establishment zone (Table 3). The white mulch reflected more $P A R$ than from the black mulch. This increase in $P A R$ available to the plant could increase the rate of photosynthesis. The amount of blue light, which influences stem thickening and length (Tanada, 1984), was greater over the white surface than over the black surface. The relative $\mathrm{R}: F R$ ratio was slightly greater over the black than over the white surfaces. The R:FR ratio is involved in phytochrome action in plants and has been implicated to regulate stem elongation, chloroplast development, and photosynthate partitioning among shoots, roots, and developing fruit (Kasperbauer, 1987). Differences in the plant light environment in the present study were similar to those previously reported under field conditions to affect tomato plant growth and fruit yields (Decoteau et al., 1989; Orzolek et al., 2000).

Mulch surface color slightly affected root-zone temperatures (Table 3 ); however, the average soil temperatures for both mulch treatments were within the biologically acceptable range for tomato (Gosselin and Trudel, 1984). Our previous experiences (Decoteau et al., 1988, 1989) have suggested that the relatively small differences in soil temperature that we observed in the present experiment are not entirely responsible for the observed growth differences of tomato over the mulch treatments and that other environmental variables such as reflected light from the mulch are impacting plant growth.

These results continue to advance our knowledge on how surface color of mulch can influence plant growth and development, and provide evidence that leaf area distribution of tomato is affected by the surface color of the mulch. The effects of much surface color on leaf area distribution appear to be triggered by differences in the reflected light off of the plastic surface into the plant canopy and are consistent with our previous observations (Decoteau et al., 1988). Mulch surface color effects on leaf area may subsequently affect early fruiting and contribute to yield differences previously reported in field trials with tomatoes (Decoteau et al., 1989; Fortnum et al., 1997; Kasperbauer and Hunt, 1998; Orzolek et al., 2000 ) and other crops (Orzolek et al., 2000). In addition, other environmental factors not recorded in the present study such as air temperature and humidity near the foliage may have also contributed to some of the observed differences in plant growth. Although the color of mulch recommended for a specific fruit or vegetable crop, location, and season still needs further evaluations, insights into the physiological mechanisms that contribute to plant growth and production modifications with the use of surface-reflective mulches should assist in the development of new mulches and protocols for desired plant development (shape) and improved production (fruiting).

\section{Literature cited}

Andegoroye, A.S. and P.A. Jolliffe. 1983. Initiation and control of sunscald injury of tomato fruit. J. Amer. Soc. Hort. Sci. 108:23-28.

Aung, L.H. and W.C. Kelly. 1966. Influence of defoliation on vegetative, floral and fruit development in tomatoes (Lycopersicon esculentum Mill.). Proc. Amer. Soc. Hort. Sci. 89:563570.

Decoteau, D.R. 1990. Tomato leaf development and distribution as influenced by leaf removal and decapitation. HortScience 25:681-684.

Decoteau, D.R. 2005. Principles of plant science: Environmental factors and technology in growing plants. Pearson Prentice Hall, Upper Saddle River, NJ.

Decoteau, D.R., D.D. Daniels, M.J. Kasperbauer, and P.G. Hunt. 1986. Colored plastic mulches and tomato morphogenesis. Proc. Natl. Agr. Plastics Congr. 19:240-248.

Decoteau, D.R., M.J. Kasperbauer, D.D. Daniels, and P.G. Hunt. 1988. Plastic mulch color effects on reflected light and tomato plant growth. Scientia Hort. 34:169-175.

Decoteau, D.R., M.J. Kasperbauer, and P.G. Hunt. 1989. Mulch color affects yield of fresh market tomatoes. J. Amer. Soc. Hort. Sci. 114:216-220.

Fisher, K.J. 1977. Competition effects between fruit trusses of the tomato plants. Scientia Hort. 8:37-42.

Fortnum, B.A., D.R. Decoteau, and M.J. Kasperbauer. 1997. Colored mulches affect yield of fresh-market tomato infected with Meloidogyne incognita. J. Nematol. 29:538-546.

Fortnum, B.A., D.R. Decoteau, and M.J. Kasperbauer. 2000. Effect of mulch surface color on root-knot of tomato grown in simulated planting beds. J. Nematol. 32:101-109.

Gosselin, A. and M.J. Trudel. 1984. Interactions between air and root temperatures on greenhouse tomato: I. Growth, development and yield. J. Amer. Soc. Hort. Sci. 108:901-905.

Hussey, G. 1963. Growth and development in young tomato. I. The effect of temperature and light intensity on growth of the shoot apex and leaf primordial. J. Expt. Bot. 14:316-325.

Jones, T.L., U.S. Jones, and D.O. Ezell. 1977. Effect of nitrogen and plastic mulch on properties of Troup loamy sand and yield of 'Walter' tomatoes. J. Amer. Soc. Hort. Sci. 102:273-275.

Kasperbauer, M.J. 1987. Far-red reflection from green leaves and effects of phytochrome-mediated partitioning 
under field conditions. Plant Physiol. 85:350-354.

Kasperbauer, M.J., H.A. Borthwick, and S.B. Hendricks. 1964. Reversion of phytochrome 730 (Pfr) to P660 (Pr) in Chenopodium rubrum L. Bot. Gaz. 125:75-90.

Kasperbauer, M.J. and P.G. Hunt. 1998. Far-red light affects photosynthate allocation and yield of tomato over red mulch. Crop Sci. 38:970-974.

Nesbitt, T.C. and S.D. Tanksley. 2001. fw2.2 directly affects the size of developing tomato fruit, with secondary effects on fruit number and photosynthate distribution. Plant Physiol. 127:575-583.

Orzolek, M.D., L. Otjen, and J.E. Fleck. 2000. Update: Effect of colored mulch on pepper and tomato production. Proc. Intl. Natl. Agr. Plastics Congr. 29:321-329.
Paul, E.M.M. 1984a. The response to temperature of leaf area in tomato genotypes. I. Cell size and number in relation to the area of a leaf. Euphytica 33:347354 .

Paul, E.M.M. 1984b. The response to temperature of leaf area in tomato genotypes. II. The rate of leaf production. Euphytica 33:355362 .

Smith, D.F. 1968. Mulching systems and techniques. Proc. Natl. Agr. Plastics Conf. 8:112-118.

Tanada, T. 1984. Interactions of green or red light with blue light on the dark closure of Albizzia pinnules. Physiol. Plant. 61:35-37.

Tucker, D.J. 1977. The effects of far-red light on lateral bud outgrowth in decapitated tomato plants and the associated changes in the levels of auxin and abscisic acid. Plant Sci. Lett. 8:339-344.

Vanderberg, J. and H. Tiessen. 1972. The influence of wax-coated and polyethylenecoated mulch on the growth and flowering of tomato. HortScience 7:464-465.

Veliath, J.A. and A.C. Ferguson. 1972. The effect of deblossoming on fruit size, yield, and earliness in tomato. J. Hort. Sci. 7:278-279.

Wien, H.C. and P.L. Minotti. 1987. Growth, yield, and nutrient uptake of transplanted fresh-market tomatoes as affected by plastic mulch and initial nitrogen rate. J. Amer. Soc. Hort. Sci. 112: 759-763.

Wolk, J.O., D.W. Kretchman, and D.G. Ortega. 1983. Response of tomato defoliation. J. Amer. Soc. Hort. Sci. 108: 536-540. 